\title{
PRODUCTIVE AND REPRODUCTIVE PERFORMANCE OF FRIESIAN COWS RAISED UNDER THE EGYPTIAN CONDITION
}

\author{
Safaa S. Sanad ${ }^{1}$, A. E. Kadry ${ }^{2}$, M.A. Aboul-Hassan ${ }^{2}$ and M.I. Shehab El-Din ${ }^{2}$ \\ 1- Animal Production Research Institute, Agric. Research Center, Ministry of Agric. Dokki, Giza, Egypt, 2- \\ Department of Animal Production, Faculty of Agriculture, Al-Azhar University, Cairo, Egypt \\ Corresponding author: dr_safaasalah@yahoo.com
}

Received: 5/9/2019 Accepted: 14/10/2019

\section{SUMMARY}

The objectives of this study were to predict the influence of sire and some environmental factors on milk traits and reproduce ability and estimate heritability, genotypic correlation and breeding value of cows, sire and dam. A total of 1976 records were collected for over 12 years from Alkarda farm (Government farm) located in Kafr El-sheikh governorate, the dairy herd belongs to Animal Production Research Institute (APRI), Egypt. Studied traits were productive and reproductive traits including total milk yield (TMY, $\mathrm{kg}$ ), 305-day milk yield (305-DMY, kg), lactation period (LP), days open (DO) and calving interval (CI). The analysis was performed using: General linear model (GLM) procedure (SAS, 2003) to determine the fixed effects (parity, year and season of calving) and random effects of sire. Data were analyzed by Multiple Traits Derivative Free Restricted Maximum Likelihood (MTDFREML) according to Boldman et al. (1995) to estimate variance components, heritability and breeding value of cow, sire and dam using Best linear unbiased prediction (BLUP) calculated by back solution for all animals in the pedigree file. Actual means of TMY, 305-DMY, LP, DO and CI were $3361.9 \mathrm{~kg}, 2939.1 \mathrm{~kg}, 310$ day, 148.7 day and 451 day, respectively. The study showed significant effects of sires selection on all traits, allows the possibility of selection to improve these traits through sires, also nongenetic effects of parity, year and season of calving affected $(P \leq 0.001)$ all traits. Heritability estimates for TMY, 305-DMY, LP, DO and CI were 0.31, 0.34, 0.31, 0.03 and 0.04, respectively. Rank correlation computed between predicted breeding values among TMY, 305-DMY and LP were highly significant $(P \leq 0.001)$ ranging from (0.40 to 0.89) showing that genetic improvement of one of the trait improve the rest of the traits. Genetic correlations $\left(r_{g}\right)$ between milk and reproduce ability traits ranged from 0.001 to 0.078 . Wide range of cows breeding value was found for most of the studied traits for TMY, 305-DMY, LP, DO and CI were $3278 \mathrm{~kg}, 2726$ $\mathrm{kg}, 329.9$ day, 10.2 day, and 48.9 day, respectively. Selection cows leads to high genetic improvement in the herd.

Keywords: Friesian, productive and reproductive traits, genetic parameters, government farm Egypt

\section{INTRODUCTION}

Milk production and reproducibility are important economic traits that form most of the income resources for dairy farmers worldwide.

The dairy industry in Egypt has undergone substantial changes during the last two decades (Rushdi et al., 2014). Generally, the increase in milk production can be achieved either by increasing number of milking cows or by improving milk production per animal through improving the environmental conditions, management practices and genetics make up of animals. The ultimate goal of any breeding program is the genetic improve to of the traits defined in the breeding model set for the dairy population. The traditional approach to achieve this is to select the superior animals to be parents for the next generation and among them to decide which should allowed to have the largest number of offspring (Strandberg and Malmfors, 2006). The genetic composition of the population, thereafter can be decided by evaluating of the residents the relative importance of heredity and environmental factors affecting the performance of that population (Goshu et al., 2014). In this regard, Knowledge of the heritability's values and phenotypic and genetic correlations between the traits are needed to calculate genetic merits, predict response to selection, help the producer to choose the right a breeding system to be adopted for future improvement (Cassell, 2001) and moreover, evaluate the breeding plan as well and to predict breeding values of the animals (Sahin et al., 2012).Animal model is currently the most that is factory statistical method to predict animal's breeding value (PBV) and their higher than of all available information from relatives taking into account the fixed effects and allowing comparisons among bulls, dams and cows based on breeding values(BVs) and comparison of cows across herds (Zahed et al., 2003).

The objectives of the present study were to: Predict the influence of sire and estimate the effect of some non-genetic factors on milk production traits such as total milk yield, 305-day milk yield and lactation period and reproductive traits such as days open and calving interval of Friesian cattle raised in Egypt, estimate genetic parameters (heritability, 
genetic and phenotypic correlations. and estimate cow, sire and dam breeding values.

\section{MATERIALS AND METHODS}

\section{The Source of data:}

Data used in the present study was obtained from the history sheets of lactation records of Friesian cattle maintained at El-Karada Experimental station, located in the northwest of the Nile Delta in Kafr Elsheikh governorate. This herd belong to the Animal Production Research Institute (APRI), Agricultural Research Center (ARC), Dokki, Giza, Egypt. A total number of 1976 normal lactation records of Friesian cattle over twelve consecutive years from 2007 to 2018 were used.

\section{Feeding and management:}

Cows of that herd were kept under the regular system of feeding and management adopted by the Research Center, Ministry of Agriculture. Dried off cows were fed on Egyptian clover (berseem) (Trifolium alexandrinum) from November till midMay. However, cows in milk grazed berseem from 10:00 a.m. to 2:00 p.m. and then were given rice straw at the rate of $4 \mathrm{~kg} /$ animal. concentrate mixture plus to cover about $60 \%$ of their requirements. In summer (mid-May to November), the animals were fed on concentrate mixture, rice straw and berseem hay if available. Concentrate supplementary ration contained at least $14-16 \%$ crude protein and $65 \%$ total digestible nutrient.

\section{Data collection:}

A summary of the data available for analysis in Table (1). The productive traits were total milk yield (TMY/kg), 305-Day Milk Yield (305-DMY/ kg) and Lactation Period (LP/day) and the reproductive traits were days open (DO/day) and calving interval (CI/day).

\section{Data analysis:}

Data were analyzed using the general linear model (GLM) procedure (SAS, 2003) recording to the mixed model:

Where:

$$
\mathrm{Y}_{\mathrm{ijklm}}=\mu+\mathrm{S}_{\mathrm{i}}+\mathrm{P}_{\mathrm{j}}+\mathrm{Y}_{\mathrm{k}}+\mathrm{SE}_{\mathrm{l}}+\mathrm{e}_{\mathrm{ijklm}}
$$

\section{Table 1. Summary of Data available for analysis}

\begin{tabular}{lc}
\hline Item & Number \\
\hline Records of productive traits & 1976 \\
Records of reproductive traits & $1648 *$ \\
Sires & 117 \\
Dams & 356 \\
Cows & 471 \\
\hline
\end{tabular}

* Reproductive data were recorded from $2{ }^{\text {nd }}$ parity and after

\section{RESULTS AND DISCUSSION}

Means, standard deviation (SD) and coefficients of variation ( $\mathrm{CV} \%)$ for milk traits produce ability and reproduce ability of Friesian cows are in table (2). Milk traits are within the ranges reported in
$\mathrm{Y}_{\mathrm{ijklm}}$ : either TMY, 305-DMY, LP, DO or CI

$\mu=$ Population mean for each respective respective trait,

$\mathrm{S}_{\mathrm{i}}=$ the random effect of $\mathrm{i}^{\text {th }}$ sire,

$P_{j}=$ the fixed effect of $j^{\text {th }}$ parity $(j=1,2 \ldots 7)$,

$\mathrm{Y}_{\mathrm{k}}=$ the fixed effect of $\mathrm{k}^{\mathrm{th}}$ year of calving $(\mathrm{k}=2007 \ldots$ 2018),

$\mathrm{SE}_{\mathrm{l}}=$ the fixed effect of $1^{\text {th }}$ season of calving $(1=1$, $2 \ldots 4)$,

$\mathrm{e}_{\mathrm{ijklm}}=$ random residual assumed to be independent normally distributed with mean zero and variance $\sigma^{2} \mathrm{e}$.

\section{Genetic parameters:}

Heritability and predicted breeding values (PBV) for all studied traits were estimated using single trait animal model (STAM). Multi-trait derivative-free restricted maximum likelihood MTDFRAML program of Boldman et al. (1995) obtained by REML method of VARCOMP procedure (SAS, 2003) was also realized the main fixed effects and interactions were tested and then removed from the model for being non-significant. The analytical model included fixed effects

The model was : $\mathrm{Y}=\mathrm{Xb}+\mathrm{Z}_{1} \mathrm{a}+\mathrm{Z}_{2} \mathbf{p e}+\mathrm{e}$

Where,

Y: a vector of observations, b: a vector of fixed effects with an incidence matrix $\mathrm{X}$, a and $\mathrm{p}_{\mathrm{e}}$ : a vector of additive genetic and permanent environmental effect with incidence matrix $Z_{1} ; Z_{2}$ and e: a vector of residual effects with mean zero and variance $\sigma^{2}$.

Predicted breeding values (PBV):-

Best linear unbiased prediction (BLUP) PBV was calculated by back solution using the MTDFREML program for all animals in the pedigree file. Cow breeding values (CBVs) were producing using their own records, while dam and sire PBVs were obtained without own records.

\section{Genetic correlation:}

Genetic correlations among PBV from (BLUP) rank correlation among ranks were estimated.

Phenotypic correlation among all traits under study were estimated previous studies under similar conditions (Hussein et al., 2016 and Abo-Elenin, 2018). However, these means were relatively lower than those reported in other Egyptian studies on (Friesian) or Holstein cattle in commercial herds (Faid-Allah, 2015a; El-Awady et al., 2016 and Sanad and Hassanane, 2017). 
Despite of the appropriate over all mean of lactation period (310.08day), both TMY and 305DMY were low (about $10 \mathrm{~kg} /$ day) compared to the global standards (above $25 \mathrm{~kg} /$ day )probably due to low genetic potentials and unfavorable management factors Kapoor (2014) reported similar low milk production $(7.1 \mathrm{~kg} /$ day) under Indian environmental conditions. However Sanad and Afifi, (2016) obtained high means of TMY and 305-DMY (4140kg and $3630 \mathrm{~kg}$, respectively) under intensive production systems for H- Friesian cows in Egypt. Rushdi et al. ( 2014), Hussein et al. (2016) and AboElenin (2018) obtained high milk production to the genetic makeup of the imported Friesian cows and to the fund management conditions under which cows made their lactation in Egypt.

The present mean of DO 148.71day was higher than that obtained by Shalaby et al. (2013) on Friesian cattle in Egypt (121day) and El-Awady et al. (2016) (120 day), but was slightly lower than (e.g. Faid-Allah, 2015 a, b) and El-Tarabanyand Nasr, 2015) (154-158 day)and much lower than those reported by Ayalew et al. (2017) and Abo-Elenin (2018) on commercial Holstein and Friesian cow 162-184.5 day. The present CI mean was 451 day within the ranges, reported in the Egyptian studies Sanad (2006) (452day) and Abo-Elenin, 2018 (445 day), but was higher than range of 401.1 to 438 day El-Tarabany and El-Bayoumi (2015) and El-Awady et al. (2016) and lower than 470 day Salem et al. (2006), 484 day (Ibrahim et al., 2009) and 472 day (Farrag et al., 2017) Shalaby et al. (2001) and Hammoud et al. (2010) reported that the variation in the reproductive traits of Friesian cattle raised under Egyptian environmental may be due to the differences in management policies for breeding practices among Friesian herds in and/or to the poor experience in estrus detection which lead to delay fertile insemination and consequently increase CI. In this regard, Farrag et al., (2017). They attributed that to the poor nutrition, genetics and/or managerial conditions which load to lower cow fertility.

\section{Coefficients of variation:}

Variability for all studied traits as measured by $\mathrm{CV} \%$ were high but within the ranges reported for Friesian cows in Egypt (El-Awady et al., 2016; Sanad and Hassanane, 2017 and Abo-Elenin 2018). However, CV\% reported by Afifi et al. (2002) and Salem et al. (2006) for TMY and 305 DMY (Sanad, 2006 and Hammoud, 2013) were lower ranging between 5.0 and 18.6 for milk production traits of Holstein commercial herd. The CV\% values for DO and CI were surprisingly lower than those for milk yield but were within the ranges of the Friesian cows reported by Faid-Allah (2015a, b), El-Awady et al., 2016 and Abo-Elenin, 2018.

Higher $\mathrm{CV} \%$ are primary evaluation for the size of variation in the given trait of concern that could be utilized to improve the performance of Friesian cows in Egypt for milk and reproductively traits. Moderate $\mathrm{CV} \%$ for $\mathrm{CI}$ and DO compared to milk production in the current study reflects high accuracy in estrus detection and low insemination.

Table 2. Means, standard deviations (SD) and coefficients of variation (CV\%) milk production and reproducibility traits of Friesian cattle.

\begin{tabular}{lccc}
\hline Traits & Mean & SD & CV\% \\
\hline TMY & 3361.86 & 1199.54 & 35.68 \\
305-DMY & 2939.08 & 1018.77 & 34.66 \\
LP & 310.08 & 113.04 & 36.45 \\
DO & 148.71 & 0.854 & 23.33 \\
CI & 451.03 & 2.60 & 23.48 \\
\hline
\end{tabular}

\section{Non genetic factors effects :}

Least-square estimates and significance of the factors affecting the studied traits are in table (3). The studied non-genetic factors affected most of milk production traits TMY, 305-DMY, LP, DO and CI $(\mathrm{P} \leq 0.05, \quad \mathrm{P} \leq 0.01$ or $\mathrm{P} \leq 0.001)$ except season of calving on DO and CI which were not significant. Also parity and sire had non-significant effect on CI, similar to the results found by Ashour et al. (2014); Rushdi (2015) and Sanad (2016).

Sire revealed high significant $(\mathrm{P} \leq 0.001)$ source of variation for milk production traits indicating good the possibility of getting genetic progress selection throw, sire. Is in agreement Al-Samarai et al. (2015) and Sanad (2016).

The results year of calving affected on 305-DMY and LP $(\mathrm{p} \leq 0.001)$ and TMY $(\mathrm{P} \leq 0.01)$. The same trend was observed by Faid-Allah (2015a); Hussein et al. (2016); Salem and Hammoud (2016) and AboElenin (2018). Also, Sanad and Afifi, (2016) noticed that parity and year of calving had significant effect on TMY and LP for Friesian cow raised in Egypt. Ihalem et al. (2012) reported significant effect of CI. Sanad (2016) reported a high effect on those traits except the effect on CI.

Year of calving also affected $(\mathrm{P} \leq 0.001) \mathrm{DO}$ and CI. The same trend was observed by Hussein et al. (2016); Salem and Hammoud, (2016) and AboElenin (2018) on different cattle breeders.

\section{Genetic aspects: \\ Heritability estimates:}

Heritability $\left(\mathrm{h}^{2}\right)$, direct permanent environmental variance $\left(\mathrm{P}_{\mathrm{e}}\right)$ and environmental variance (e) estimates of TMY, 305-DMY, LP, DO and CI are presented in (table 4). The current estimates were in 
similar ranges for Friesian cattle as those observed by Faid-Allah (2015a) El-Bayoumi et al. (2015); AlSamarai et al. (2015) and Sanad (2016) whose estimates ranged from 0.22 to 0.35 for TMY, 0.25 to 0.36 for 305-DMY, 0.22 to 0.35 for LP, from 0.01 to 0.07 for DO and from 0.02 to 0.07 for CI.
Direct permanent environmental estimates were lower than those reported by Khattab et al. (2005) while were higher than those obtained by Sanad and Hassanane (2017) for TMY, 305-DMY and LP being $0.009,0.00012$ and 0.0049 , respectively.

Table 3. Least-squares analysis of variance of factors affecting milk and reproducability traits of Friesian cattle.

\begin{tabular}{|c|c|c|c|c|c|c|c|}
\hline \multirow[b]{2}{*}{ Item } & \multirow[b]{2}{*}{ No. } & TMY (kg.) & 305-DMY (kg.) & LP (day) & \multirow[b]{2}{*}{ No. } & \multirow{2}{*}{$\begin{array}{c}\text { DO (day) } \\
\text { Means } \pm \text { SE }\end{array}$} & \multirow{2}{*}{$\begin{array}{c}\text { CI (day) } \\
\text { Means } \pm \text { SE }\end{array}$} \\
\hline & & Means \pm SE & Means \pm SE & Means \pm SE & & & \\
\hline Overall mean & 1976 & $3361.86 \pm 26.98$ & $2939.08 \pm 22.91$ & $310.08 \pm 2.54$ & 1649 & $148.71 \pm 0.85$ & $451.03 \pm 2.61$ \\
\hline \multicolumn{8}{|l|}{ Year of calving } \\
\hline 2007 & 199 & $3399.2 \pm 82.53$ & $2998.7 \pm 67.69$ & $317.88 \pm 8.87$ & 161 & $153.13 \pm 2.87$ & $452.29 \pm 9.29$ \\
\hline 2008 & 195 & $3795.6 \pm 80.19$ & $3352.6 \pm 65.78$ & $321.79 \pm 8.62$ & 160 & $144.92 \pm 2.94$ & $454.95 \pm 9.53$ \\
\hline 2009 & 194 & $3673.6 \pm 86.17$ & $3166.3 \pm 66.62$ & $309.77 \pm 8.73$ & 153 & $150.95 \pm 2.93$ & $444.63 \pm 9.48$ \\
\hline 2010 & 191 & $3519.8 \pm 83.14$ & $3182.1 \pm 68.19$ & $294.73 \pm 8.94$ & 152 & $149.97 \pm 2.94$ & $438.81 \pm 9.52$ \\
\hline 2011 & 187 & $3238.3 \pm 86.17$ & $2888.6 \pm 70.68$ & $313.48 \pm 9.26$ & 147 & $155.93 \pm 2.93$ & $482.30 \pm 9.49$ \\
\hline 2012 & 186 & $3633.6 \pm 89.67$ & $3151.6 \pm 69.17$ & $313.35 \pm 9.06$ & 147 & $153.73 \pm 3.13$ & $443.64 \pm 10.1$ \\
\hline 2013 & 164 & $2831.9 \pm 92.89$ & $2510.6 \pm 76.19$ & $322.40 \pm 9.98$ & 143 & $131.87 \pm 3.17$ & $463.93 \pm 10.2$ \\
\hline 2014 & 153 & $3827.7 \pm 89.67$ & $3231.8 \pm 73.55$ & $310.28 \pm 9.64$ & 139 & $174.69 \pm 3.36$ & $436.95 \pm 10.8$ \\
\hline 2015 & 146 & $2591.8 \pm 89.67$ & $2200.9 \pm 82.50$ & $310.28 \pm 10.81$ & 125 & $145.56 \pm 3.68$ & $475.86 \pm 11.9$ \\
\hline 2016 & 134 & $3080.8 \pm 106.1$ & $2648.7 \pm 87.03$ & $297.77 \pm 11.41$ & 118 & $133.37 \pm 3.66$ & $454.52 \pm 11.8$ \\
\hline 2017 & 123 & $2598.8 \pm 111.5$ & $2160.6 \pm 91.51$ & $300.69 \pm 11.99$ & 102 & $131.15 \pm 4.33$ & $402.63 \pm 13.9$ \\
\hline 2018 & 104 & $3837.9 \pm 108.2$ & $3465.7 \pm 88.77$ & $294.58 \pm 11.63$ & 102 & $145.03 \pm 5.57$ & $432.92 \pm 14.7$ \\
\hline \multicolumn{8}{|l|}{$\underline{\text { Season }}$} \\
\hline Autumn & 538 & $3610.83 \pm 59.3$ & $3211.04 \pm 48.65$ & $306.26 \pm 6.44$ & 449 & $147.46 \pm 2.16$ & $450.45 \pm 6.93$ \\
\hline Winter & 534 & $3503.99 \pm 59.9$ & $3047.40 \pm 49.15$ & $319.41 \pm 6.37$ & 406 & $151.32 \pm 2.16$ & $454.78 \pm 6.98$ \\
\hline Spring & 479 & $3300.66 \pm 61.2$ & $2877.20 \pm 50.22$ & $313.76 \pm 6.62$ & 431 & $149.80 \pm 2.18$ & $452.17 \pm 7.37$ \\
\hline Summer & 425 & $3075.40 \pm 61.2$ & $2669.02 \pm 50.55$ & $301.98 \pm 6.584$ & 363 & $146.24 \pm 2.28$ & $447.03 \pm 7.37$ \\
\hline \multicolumn{8}{|l|}{ Parity } \\
\hline 1 & 327 & $2932.64 \pm 68.13$ & $2543.50 \pm 55.88$ & $268.08 \pm 8.50$ & 326 & $143.07 \pm 2.35$ & $436.38 \pm 7.60$ \\
\hline 2 & 326 & $3027.92 \pm 68.31$ & $2611.73 \pm 56.03$ & $279.21 \pm 8.97$ & 311 & $149.81 \pm 2.43$ & $450.78 \pm 7.87$ \\
\hline 3 & 311 & $3245.94 \pm 70.76$ & $2742.98 \pm 58.00$ & $278.21 \pm 7.60$ & 310 & $150.51 \pm 2.44$ & $457.27 \pm 7.89$ \\
\hline 4 & 310 & $3367.89 \pm 70.71$ & $2987.32 \pm 58.04$ & $351.44 \pm 7.32$ & 263 & $154.57 \pm 2.47$ & $456.25 \pm 7.98$ \\
\hline 5 & 263 & $3823.55 \pm 83.50$ & $3505.49 \pm 68.49$ & $340.92 \pm 7.34$ & 231 & $148.39 \pm 2.86$ & $454.40 \pm 9.26$ \\
\hline 6 & 231 & $3751.03 \pm 79.13$ & $3287.15 \pm 64.90$ & $325.64 \pm 7.60$ & 208 & $145.06 \pm 2.84$ & $454.32 \pm 9.20$ \\
\hline 7 & 208 & $3732.45 \pm 73.73$ & $3258.05 \pm 60.47$ & $300.94 \pm 7.92$ & 326 & $143.07 \pm 2.35$ & $436.38 \pm 7.60$ \\
\hline
\end{tabular}

$\mathrm{NS}=$ not significant, $*=\mathrm{P} \leq 0.05, * *=\mathrm{P} \leq 0.01, * * *=$ significant at $\mathrm{P} \leq 0.001$

Table 4. Habitability (h), (P) and error (e) for productive and reproducability traits of Friesian cattle

\begin{tabular}{cccc}
\hline Traits & $\mathbf{h}_{\mathbf{a}} \mathbf{P}$ & $\mathbf{P e}$ & $\mathbf{E}$ \\
\hline TMY & $0.31 \pm 0.026$ & $0.035 \pm 0.035$ & $0.65 \pm 0.041$ \\
305-DMY & $0.34 \pm 0.028$ & $0.005 \pm 0.030$ & $0.64 \pm 0.041$ \\
LP & $0.31 \pm 0.001$ & $0.008 \pm 0.001$ & $0.70 \pm 0.001$ \\
DO & $0.03 \pm 0.002$ & $0.004 \pm 0.0030$ & $0.97 \pm 0.003$ \\
CI & $0.04 \pm 0.001$ & $0.0001 \pm 0.001$ & $0.96 \pm 0.002$ \\
\hline
\end{tabular}

$\mathrm{h}^{2}=$ heritability, $\mathrm{P}^{2}=$ Direct permanent environmental variance effect and $\mathrm{e}=$ residual variance.

\section{Genetic correlation :}

Unfavorable low positive non-significant genetic correlations were observed between milk and reproduce ability traits in (Table 5). Except between TMY and CI which was negative (-0.04), between LP and $\mathrm{CI}$ was significant $(\mathrm{P} \leq 0.05)$. Improving milk production of dairy cows is usually association with low fertility. Toghiani (2012a) and Shalaby et al. (2013) pointed to the unfavorable positive genetic associations between reproductive traits and milk yield traits (TMY, 305-DMY and LP). In the same trend, Tawfik et al. (2000) working on Friesian cattle reported that high-yielding cows and therefore have long CI tended to lactate for a long time. Contrarily, Hammoud (2013); El-Bayoumi et al. (2015) and Sanad and Gharib (2017a) represented negative genetic correlation between milk production traits and DO. Therefore special attention should be paid for cow fertility when selection is practiced for milk production.

However, Ojango and Pollot, (2001) and ElBayoumi et al. (2015) claimed that the antagonistic relationship between TMY and CI (-0.64) and ($0.99)$, respectively were due to environmental factors rather than genetic. And they suggested that the genes that affect the milk production positively are 
likely not related CI. running on the same argument, Rearte et al. (2018) reported that, the magnitude of the relationship between milk yield and reproductive performance genetically is small, and depending mainly on level of herd production. All factors would cause correlations to be differ (Toghiani, 2012a).

Table 5. Rank correlation between predicted breeding values of milk traits and reproducability (below diagonal) and phenotypic correlation between the some traits (above diagonal)

\begin{tabular}{cccccc}
\hline & TMY & 305-DMY & LP & DO & CI \\
\hline TMY & & $0.720^{* *}$ & $0.159^{*}$ & $-0.032^{\mathrm{ns}}$ & $-0.011^{\mathrm{ns}}$ \\
DMY & $0.898^{* *}$ & & $0.025^{\mathrm{ns}}$ & $-0.010^{\mathrm{ns}}$ & $-0.012^{\mathrm{ns}}$ \\
LP & $0.444^{* *}$ & $0.423^{* *}$ & & $0.04^{\mathrm{ns}}$ & $0.039^{\mathrm{ns}}$ \\
DO & $0.078^{\mathrm{ns}}$ & $0.066^{\mathrm{ns}}$ & $0.082^{\mathrm{ns}}$ & & $0.247^{* *}$ \\
CI & $-0.0452^{\mathrm{ns}}$ & $0.001^{\mathrm{ns}}$ & $0.160^{*}$ & $0.405^{* *}$ & \\
\hline
\end{tabular}

$*=$ significant at $\mathrm{P} \leq 0.05, * *=$ significant at $\mathrm{P} \leq 0.01, \mathrm{~ns}=$ Non-significant

$\mathrm{TMY}=$ total milk yield, $305-\mathrm{DMY}=305$-day milk yield, $\mathrm{LP}=$ lactation period , $\mathrm{DO}=$ days open and $\mathrm{CI}=$ calving interval.

\section{Phenotypic correlation coefficients:}

Phenotypic correlation coefficients $\left(r_{p}\right)$ among milk production and reproductive traits are given in table 5 (above diagonal). All phenotypic correlations between productive traits (TMY, 305-DMY and LP), were positive. Strong positive $r_{p}$, very low but were negative with DO and LP.

Similar result were reported by (Sanad and Afifi, 2016; Sanad, 2016 and Sanad and Gharib, 2017a). Their estimates ranged from 0.08 to 0.85 , from 0.14 to 0.75 and from 0.005 to 0.70 for TMY with 305 DMY, TMY with LP and 305-DMY with LP, respectively. On the other hand, low positive phenotypic correlations were observed between DO and CI. Similar results were mentioned by Hammoud (2013), El-Awady et al. (2017) and Abo-Elenin (2018).

Negative $r_{p}$ between TMY and 305-DMY with DO and CI, were also calculated by Faid-Allah

\section{Breeding values $(\mathrm{BV})$ :}

Estimates of breeding values (EBVs) of cows, dams and sires for TMY, 305-DMY, LP, DO and CI are presented in table 6 . The present results showed that, the ranges of BV of cows, sires and dams. The highest ranges of breeding values and accuracy were among cows followed by dams and the least were among sires.

The present results show large ranged of differences among breeding values of cows, sires and dams for different traits but cows, sires and dams with positive values for TMY and LP. Which indicated that, selection top cows for TMY were also positive for sires and dams will increase LP was decrease CI in next generation. El-Arian et al. (2002) and Sanad (2016) arrived at the same conclusion on Friesian cows. The high range of breeding values of cows compared to those of sires and dams may be due to using few numbers of proven sires compared to using large number of dam and cows and thus making good media for selection in dams and cows. Moreover, selection of cows for the next generation would lead to higher genetic improvement in the herd. The same trends were obtained by (Hammoud, 2013 and Sanad and Afifi, 2016). (2015b) and Sanad and Gharib (2017a). However Antagonistic positive low result were obtained between LP and each of DO (0.04) and CI (0.03) in the present study, similar results were obtained by Sanad (2016); El-Awady et al. (2017); Abo-Elenin (2018) and Sanad and Gharib (2017a). Their $r_{p}$ values ranged from 0.001 to 0.006 between LP and DO, and from 0.05 to 0.08 between LP and CI, meaning less.

Also, Faid-Allah (2015 a and b) reported positive phenotypic correlations between TMY with DO, and between LP with DO and concluded that these traits could be improved simultaneously through multi-trait selection program, However, Faid-Allah (2015b) use the regard less of the small negative or positive correlation between 305-DMY and DO, between 305-DMY and LP but not between LP and DO.

The wide range of cows breeding values for a given trait indicate more genetic variation among that gives better chance for genetic improvement through selection of the superior cows according to breeding values. Selection cows on the basis of their breeding value for such traits would be more practical and then selecting them according to their sires or dams breeding values. The same results were referenced by El-Awady et al. (2016) and Sanad and Gharib, (2017a). With regard to DO, our ranges of cows BV, less than reported by Hammoud (2013), El-Bayoumi et al. (2015), Sanad and Gharib, (2017a) and AboElenin (2018), respectively.

On the contrary, the range of BV for CI was higher than of most of those found under Egyptian conditions (El-Bayoumi et al., 2015; El-Awady et al., 2016 and Abo-Elenin, 2018) which ranged from 2.03-12.05 day.

The accuracy of prediction of minimum and maximum cow breeding values for studied traits ranged from 46 to $94 \%$., which indicated that genetic improvement can be achieved through cows. Reached conclusion, Abo-Elenin (2018), although the accuracy for BV production for the same traits ranged from 00 to $87 \%$.In this respect, Sanad (2006) presented that the accuracy for cow breeding values 
for 305-DMY, LP and CI ranged from 35 to $87 \%$. accuracy of EBVs from 73-76, 73-77, 81-88 and 78Moreover, El-Awady et al. (2016) described $79 \%$ for $305-\mathrm{DMY}, \mathrm{LP}, \mathrm{CI}$ and DO, respectively.

Table 6. Range of estimated breeding values for cows, sires and dams, standard error (SE) and percentage of accuracy

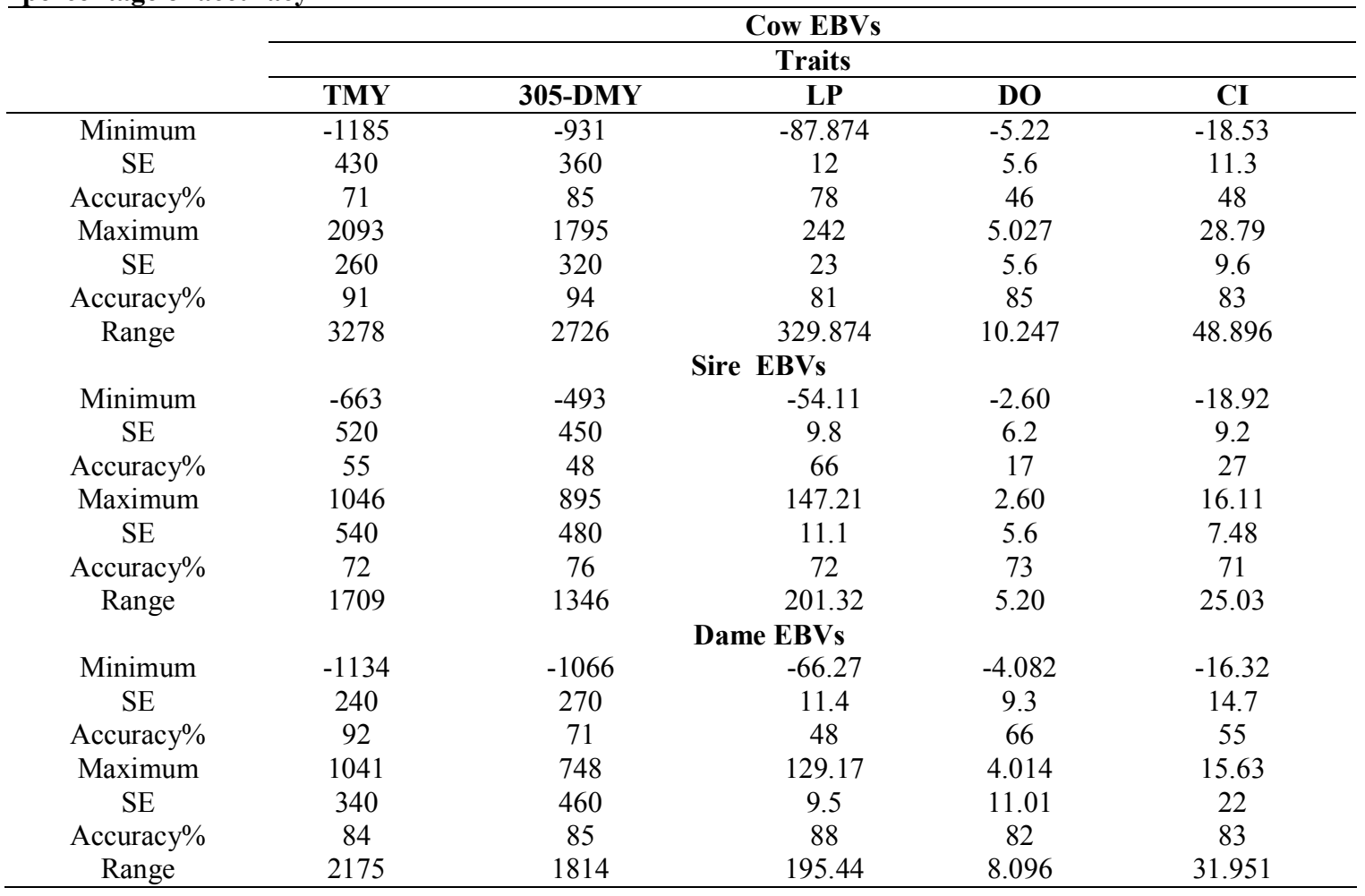

\section{CONCLUSIONS}

Moderate estimates of heritability for milk traits, high range of breeding values estimates for (cows, sires and dames) with high accuracy.

The poor performance of cows for all traits in this study compared to their contemporaries in other equivalent herds under Egyptian conditions.

Explained through investigating the following items:

- Environmental influences, which showed a negative impact on the performance, especially for milk traits,

- How influential environmental factors to reduce the adverse impacted, along with improving farm management practices,

Genetic improvement through a well-organized plan for the use of animals with higher breeding values.

\section{REFERENCES}

Abo-Elenin, A. S., 2018. Evaluation of reproductive and productive performance for Friesian, crosses and local cows under Egyptian conditions. Ph.D. Thesis, Fac. Agric., Kafr El-Sheikh Univ, Egypt.

Afifi, E. A; Khalil, M. H; Samira A. Arafa; Salem, M. A., 2002. Estimation of transmitting abilities for lactation traits using the animal model for
Holstein cattle raised under a commercial farm in Egypt. J. Agric. Sci., Mansoura Univ., 27 (1): 147-155.

Al-Samarai, F. R; Abdulrahman, Y. K; Mohammed, F. A; Al-Zaidi, F. H. and Al-Anbari, N. N. , 2015. Comparison of several methods of sires evaluation for total milk yield in a herd of Holstein cows in Yemen. Open vet. J., 5(1): 1117.

Ashour, G; Sadek, R. R; Ibrahim, M. A. M. and Samoul, A. M., 2014. Effect of housing system on productive and reproductive performance of Holstein cows in a commercial herd in Egypt. Egyptian J. Anim. Prod., 51(2): 79-87.

Ayalew, W; Aliy, M., and Negussie, E., 2017. Estimation of genetic parameters of the productive and reproductive traits in Ethiopian Holstein using multi-trait models. Asian-Aust. $J$. Anim. sci., 30(11): 1550-1556.

Boldman, K.G; Kriese, L. A; Van Vleck, L. D;Van Tassell, C. P. and Kachman, S. D., 1995. A manual for the use of MTDFREML.ARS, USDA, Clay Center, NE, USA.

Cassell, B. G., 2001. Using heritability for genetic improvement. Virginia Tech, Virginia Cooperative Extension and State University, Virginia. 
El-Arian, M.N; Alwady, N.G and Khattab, A.S. 2002. Predicting breeding values of milk production traits using an animal model of Friesian cows in Egypt. $53^{\text {rd }}$ Annual Meeting of the European.

El-Awady, H. G; Abd El-Khalek, A. E. and Abo ElReesh, M., 2016. Genetic evaluation for some productive and reproductive traits by using animal model in a commercial Friesian herd in Egypt. J. Anim. and Poult. Prod., Mansoura Univ., 7 (7): 279 - 285.

El-Awady, H. G; Salem, A. Y; Abdel-Glil, M. F; Zahed, S. M. and Abo El-Enin, A. S., 2017. Estimate of genetic and phenotypic trends for some productive and reproductive traits of Friesian cows in Egypt. J. Anim. Poult. Prod., Mansoura Univ., 8 (8): 329 - 334.

El-Bayoumi, K. M; El-Tarabany, M. S; AbdelHamid, T. M. and Mikaeil, O.M. 2015. Heritability, genetic correlation and breeding value for some productive and reproductive traits in Holstein cows. Res. Opin. Anim. Vet. Sci., 5(2): 65-70

El-Tarabany, M. S. and El-Bayoumi, K. M., 2015. Reproductive performance of backcross Holstein $\times$ Brown Swiss and their Holstein contemporaries under subtropical environmental conditions. Theriogenology, 83(3): 444-448.

El-Tarabany, M. S. and Nasr, M.A., 2015. Reproductive performance of Brown Swiss, Holstein and their crosses under subtropical environmental conditions. Theriogenology, 84(4): 559-565.

Faid-Allah, E., 2015a. Genetic and non-genetic analysis for milk production and reproductive traits in Holstein cattle in Egypt. Indonesian J. Anim. and Vet. Sci., 20(1): 10-17.

Faid-Allah, E. (2015b). Multi-trait and multi-source selection indices for milk production and reproductive traits in a herd of Holstein cattle in Egypt. Indonesian J. Anim. and Vet. Sci., 20(3): 159-167.

Farrag, F. H; Shalaby, N. A; Gabr, A.A and El Ashry, M. A., 2017. Evaluation of Friesian cattle performance at first lactation under different Egyptian conditions. J. Anim. Poult. Prod., Mansoura Univ., 8 (1): 7- 11.

Goshu, G; Singh, H; Petersson, K. J. and Lundeheim, N. 2014. Heritability and correlation among first lactation traits in Holstein Friesian cows at Holeta bull dam station, Ethiopia. International J. Livest. Prod., 5(3): 47-53.

Hammoud, M. H., 2013. Genetic aspects of some first lactation traits of Holstein cows in Egypt. Alex. J. Agric. Res, 58: 295-300.

Hammoud, M. H; El-Zarkouny, S. Z. and Oudah, E. Z. M. 2010. Effect of sire, age at first calving, season and year of calving and parity on reproductive performance of Friesian cows under semiarid conditions in Egypt. Archiva Zootechnica, 13(1): 60-82.
Hussein, k; Anas, A; Badr, A. and El-Komey, S. M., 2016. Estimation of genetic and phenotypic parameters for some milk traits on Egyptian, Friesian and their crosses cows. J. Anim. and Poultry. Prod., Mansoura Univ., 7(5): 181- 184.

Ibrahim, M. A. M; Rushdi, H. E; Abdel-Salam, S. A. M. and Abou-Bakr, S., 2009. Genetic and phenotypic trends of calving interval and age at first calving in a commercial Holstein herd. Egyptian J. Anim. Prod, 46(2): 103-112.

Ihlam, I. E; Mohmed, O.E. and Ibrahim, S. Y. 2012. Estimation of genetic and non-genetic parameters of Friesian cattle under hot climate. J. of Agric. Sci. 4 (4).

Kapoor, R., 2014. Indian cow, may your yield increase. Business line. Retrieved from:http://www.thehindubusinessline.com/opini on/indian-cow-may-your yieldincrease/article5835726.ece.

Khattab, A. S., hulya Atil and Lila Badawy (2005). Variances of direct and maternal genetic effects for milk yield and age at first calving in a herd of Friesian cattle in Egypt. Arch. Tierz., Dummerstorf 48: 1, 24-31.

Ojango, J. M. and Pollott, G. E., 2001. Genetics of milk yield and fertility traits in Holstein-Friesian cattle on large-scale Kenyan farms .J. Anim. Sci., 79(7): 1742-1750.

Rearte, R; Le-Blanc, S. J; Corva, S. G; de la Sota, R. L; Lacau-Mengido, I. M., and Giuliodori, M. J. (2018). Effect of milk production on reproductive performance in dairy herds. J. Dairy Sci., 101(8): 7575-7584.

Rushdi, H.E., 2015. Genetic and phenotypic analyses of days open and 305-day milk yield in a commercial Holstein Friesian herd. Egyptian J. Anim. Prod., 52(2): 107-112.

Rushdi, H.E; Ibrahim, M. A. M; Shaddad, N. Q. and Nigm,A. A., 2014. Estimation of genetic parameters for milk production traits in a herd of Holstein Friesian cattle in Egypt. J. Anim. and Poult. Prod., Mansoura Univ., 5 (5): 267-278.

Sahin, A; Ulutas, Z; Adkinson, A. Y. and Adkinson, R.W., 2012. Genetic and environmental parameters and trends for milk production of Holstein cattle in Turkey. Italian J. Anim. Sci., 11(3):e44: 242-248.

Salem, M. A; Esmoil, H. M; Sadek, R. R. and Nigm, A. A., 2006. Phenotypic and genetic parameters of milk production and reproductive performance of Holstein cattle under the intensive production system in Egypt. Egypt J. Anim. Prod., 43: 1-10.

Salem, M. M. I. and Hammoud, M. H., 2016. Estimates of heritability, repeatability and breeding value of some performance traits of Holstein cows in Egypt using repeatability Anim. model. Egyptian J. Anim. Prod., 53(3):147-152.

Sanad Safaa, S., 2006. Genetic analyses for some productive and reproductive traits in dairy cattle. Ph.D. Thesis, Fac., Agric., Moshtohor, Banha Univ., Egypt. 
Sanad Safaa, S., 2016.Genetic improvement using the selection indices for some productive and reproductive traits in Friesian cattle raised in Egypt. J. anim. and Poultry. prod., Mansoura Univ., 7 (12): 475- 482.

Sanad Safaa, S. and Afifi, A., 2016.Comparing genetic parameters of Friesian milk production traits in commercial and state farms in Egypt. Egypt. J. Agric. Res., 94 (4):971-984.

Sanad Safaa, S. and Gharib, M., 2017a. Epigenetics trend for some productive and reproductive traits of Friesian cattle raised in Egypt. J. Anim. and Poultry. Prod., Mansoura Univ., 8 (7): 195- 202.

Sanad Safaa, S. and Gharib, M., 2017b. Estimation of genetic parameters for some productive and reproductive traits with six different models for Friesian cattle raised in Egypt. Egypt. J. Agric. Res., 95 (3):1313-1323.

Sanad Safaa, S. and Hassanane, M.S., 2017. Genetic evaluation for some productive and reproductive traits in Friesian cows raised in Egypt. J. Anim. and Poultry. Prod., Mansoura Univ., 8 (8): 227 232.

SAS,, 2003. Statistical analysis system. SAS Release 9.1.3.For windows, SAS Institute Inc. Cary, NC, USA.

Shalaby, N. A; El-Barbary, A. S. A; Oudah, E. Z. M. and Helmy, M., 2013. Genetic analysis of some productive and reproductive traits of first lactation of Friesian cattle raised in Egypt. J. Anim. and Poult. Prod., Mansoura Univ., 4 (2): 97- 106.

Shalaby, N. A; Oudah, E. Z. M. and Abdel-Momin, M., 2001. Genetic analysis of some productive and reproductive traits and sire evaluation in imported and locally born Friesian cattle raised in Egypt. Pak. J. Bio., Sci., 4(7): 893-901.

Strandberg, E. and Malmfors, B., 2006.Selection and genetic change. Dept. of animal breeding and genetics Swedish University of Agricultural Sci., Uppsala Google Scholar.

Tawfik, E.S; Mohsen, M.K; Salem, A.Y; El-Awady, H.G., 2000. Study on Friesian herds raised in Egypt and Germany. I. Estimate of non-genetic effects and genetic parameters. Arch. Tierz., Dummerstorf 43: $101-114$.

Toghiani, S., 2012a. Genetic relationships between production traits and reproductive performance in Holstein dairy cows. Arch Tierz, 55(5): 458-468.

Turner, H. N. and Young. S.S.Y., 1969. Quantitative Genetics in Sheep Breeding. Macmillan. Melbourne, Australia.

Zahed, S. M; Salem, M. A; Khalil, M. H. and Arafa, S. A., 2003. Genetic evaluation of milk yield in Holsteins-Friesian raised in Egypt using singleand multi-traits animals models. J. Agric. Sci. Mansoura Univ., 28(2): 873-884.

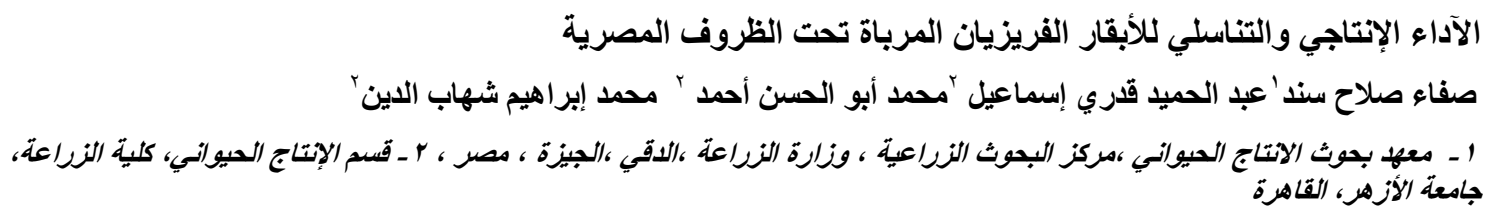

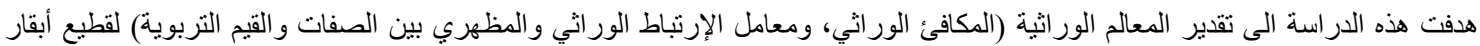

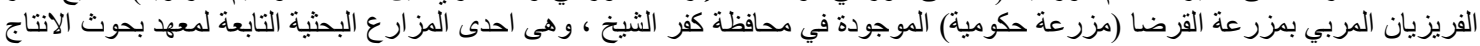

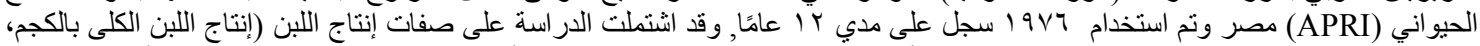

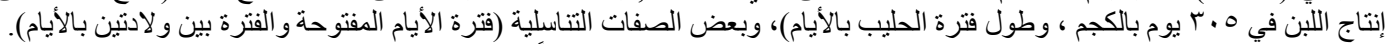

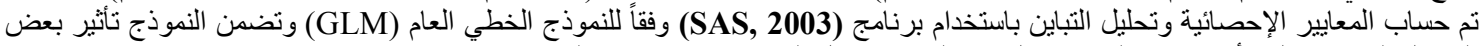

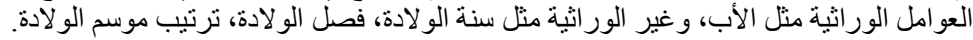

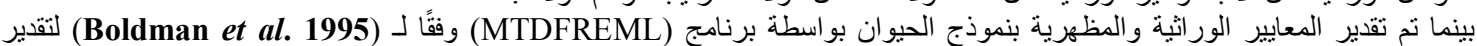

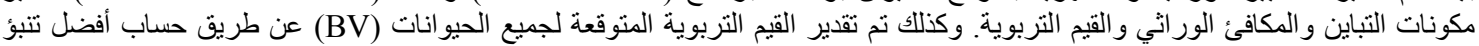

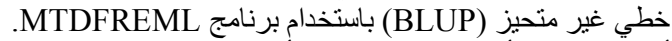

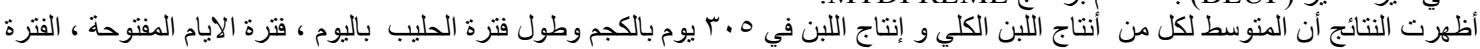

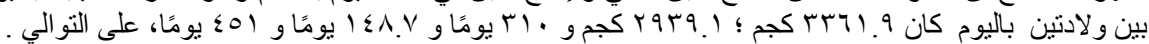

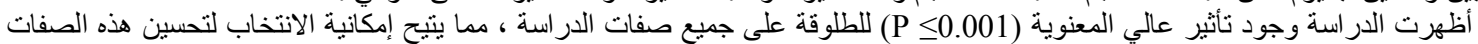

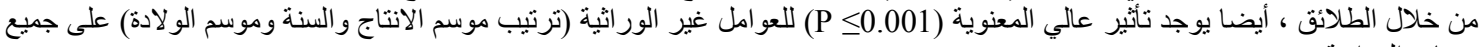
صفات الدر اسة.

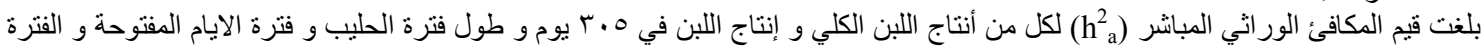

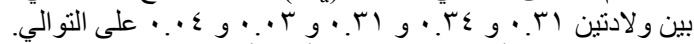

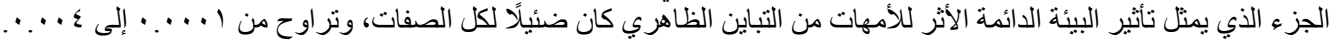

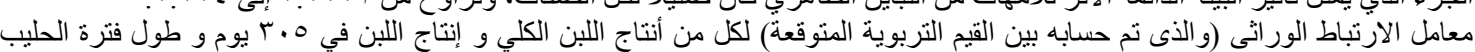

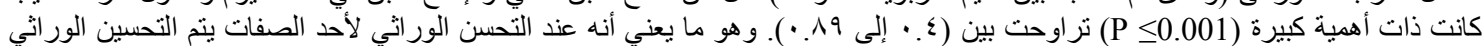

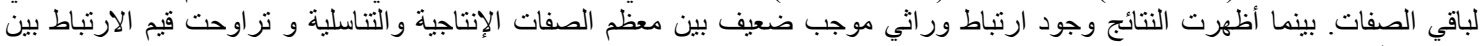

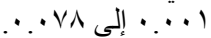

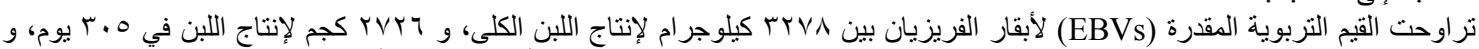

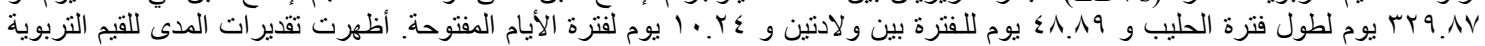

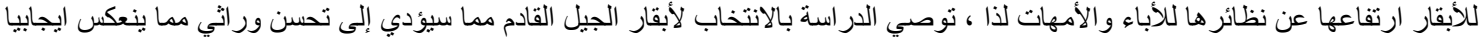
على الو اقع الانتاجي لقطيع الدراسة. 